\title{
Paleoseismic implications of fluid-escape structures in raised deltas at Lower Five Islands - Economy Point, Nova Scotia
}

\author{
Bruce E. Broster and David A. MacDougall \\ Quaternary and Environmental Studies Laboratory, Department of Geology, \\ University of New Brunswick, P.O. Box 4400, Fredericton, New Brunswick E3B 5A3, Canada \\ Date Received February 27, 1996 \\ Date Accepted August 1, 1996
}

\begin{abstract}
Deformed proglacial deltaic sediments at Economy Point - Lower Five Islands, Nova Scotia, were examined as a possible indicator of postglacial earthquake activity. The deposits represent an ice-proximal, glaciomarinedeltaic environment, that likely experienced postglacial seismic shaking. Several styles of deformation were recognized that could be attributed to penecontemporaneous deformation and are common to particular mechanisms of formation and facies. Ball and pillow structures associated with: (1) loading by rapid sedimentation, or (2) from percussion by dropstones, are common in the bottomset units. Crumpled, rolled-up or boudinaged layers were likely formed by several mechanisms, including: (1) intralayer or intra-unit compaction or stretching; (2) in association with gravity slumping, mainly in the foreset units; and (3) from loss of support due to post-depositional fluid-escape, mainly seen in association with deformation exposed in the topset units.

The fluid-escape structures are attributed to the expulsion of groundwater and sediment slurries during postglacial seismic shaking of saturated sediments. Charcoal, excavated above a fluid-escape structure in topset layers below Holocene sediment at Economy Point, has been radiocarbon dated and indicates that a significant seismic ground-disturbance may have occurred there around A.D. $1870 \pm 70$ years. Replicate sampling is needed to confirm the age of the seismic disturbance. However, if this approximate age is correct, the deformation may have resulted from the 1855 (estimated M 5+) earthquake at New Brunswick, located about $100 \mathrm{~km}$ to the west.

These preliminary results demonstrate that the physical structure of deltaic sediments can provide a record of neotectonic activity and contribute valuable data for assessment of earthquake occurrence and/or recurrence. Deformation structures associated with catastrophic fluidization of topset facies or overlying Holocene sediments are considered to be the best indicators of postglacial seismic disturbance.
\end{abstract}

On a examiné des sédiments deltaïques préglaciaires déformés à Economy Point - Lower Five Islands, en Nouvelle-Écosse, pour vérifier s'ils témoignaient d'une activité sismique postglaciaire. Les dépôts représentent un milieu glaciomarin-deltaïque proximal des glaces qui a vraisemblablement été soumis à des secousses sismiques postglaciaires. On a reconnu plusieurs types de déformations qui pourraient être attribuées à une déformation pénécontemporaine et qui sont communes aux mécanismes particuliers des formations et des faciès, notamment des structures en boules et en coussinets associées : (1) à un chargement par sédimentation rapide ou (2) à une percussion par des blocs isolés. Celles-ci sont courantes dans les unités des couches basales. Les strates plissotées, enroulées ou boudinées ont vraisemblablement été formées par plusieurs mécanismes, dont : (1) la compaction à l'intérieur des strates; (2) en association avec un glissement de terrain gravitationnel, principalement dans les unités frontales; et (3) une perte de support due à un échappement de fluides postérieur à la sédimentation, qui se manifeste surtout conjointement avec une déformation découverte dans les unités sommitales.

On attribue les structures d'échappement de fluides à l'expulsion d'eau souterraine et de bouillie de sédiments pendant les secousses sismiques postglaciaires ayant ébranlé les sédiments saturés. Le charbon impur extrait audessus d'une structure d'échappement de fluides dans les strates sommitales au-dessous des sédiments de l'Holocène à Economy Point a été daté au carbone 14 et il révèle qu'une perturbation sismique d'envergure pourrait s'être produite vers 1870 apr. J.-C. \pm 70 ans. Il faudrait effectuer un échantillonnage subdivisé pour confirmer l'âge de la perturbation sismique. Cependant, si cet âge approximatif est exact, la déformation pourrait avoir été provoquée par le tremblement de terre survenu en 1855 (estimé à plus de $5 \mathrm{M}$ ) au Nouveau-Brunswick, à environ $100 \mathrm{~km}$ à l'ouest.

Ces résultats préliminaires démontrent que la structure physique des sédiments deltaïques peut témoigner de l'activité néotectonique et qu'ils fournissent des renseignements précieux pour l'évaluation de la fréquence ou de la récurrence des tremblements de terre. Les structures de déformation associées à la fluidisation catastrophique des faciès sommitaux ou des sédiments sus-jacents de l'Holocène sont considérées comme les meilleurs indicateurs des perturbations sismiques postglaciaires.

[Traduit par la rédaction] 


\section{INTRODUCTION}

The catastrophic disturbance of unconsolidated sediment produces a wide variety of deformation structures, particularly if the sediment is water-saturated at the time of disturbance. Layers originally deposited as sub-horizontal, can become stretched or distended resulting in convoluted laminations, faulted beds, slumped units, or dewatering structures. Although produced by a variety of mechanisms, the origin of deformed sediment is often questioned in studies involving seismic hazard assessment (e.g., Broster, 1991a, 1991b). The objective of our study was to determine the origin(s) and to identify, if possible, the criteria for distinguishing between seismically-induced deformation structures and those produced by other phenomena.

The onset of deglaciation initiated a period of glacier ablation, producing a deluge of sediment-laden meltwater and a major phase of delta construction in coastal areas. In many locations "proglacial" deltas were formed adjacent to (proximally), or at some distance beyond (distally), the glacier margins. Some deltas were constructed in areas of isostatic disequilibrium, that after glaciation raised portions of the delta to subaerial levels. Because of subsequent erosion, some coastal and river exposures allow visual examination of structures within specific deltaic facies.

Here we report on deformation structures studied in two proglacial/glaciomarine deltas in the shore cliff along the Five Islands - Economy Point area, Nova Scotia (Fig. 1). The site was one of three sites in eastern Canada selected for study (see MacDougall and Broster, 1995) because it represented an ice-proximal, glaciomarine-deltaic environment, situated near a large fault that may have generated a postglacial seismic shock.

\section{Location and Geology}

The Lower Five Islands and Economy Point area of Nova Scotia, is located along the north shore of the Minas Basin (Fig. 1). Thick sequences of Pleistocene meltwater sediments occur in the area (Wightman, 1980) as glaciofluvial outwash and marine deposits that are intercalated with deltaic sediments. The units are sporadically covered by deposits related to postglacial fluvial and shore processes (Swift and Borns, 1967). Between Lower Five Islands and Economy Point, the sediments have been eroded to form a dissected raised terrace, providing shore cliff exposures in the order of 2 to $9 \mathrm{~m}$ in height. In this area, erosion has exposed parts of two deltas.

The stratigraphy and nature of the deposits have been described previously (Swift and Borns, 1967; Stea et al., 1986; MacDougall, 1996) and will be discussed here only briefly. Previous examination of these raised deltas indicated that a major period of growth occurred during deglaciation, and that the physiography of the deltas generally follows the typical "Gilbert-type" three-facies subdivision, including bottomsets, foresets and topsets (Swift and Borns, 1967; Wightman, 1980). Although the deltas formed from separate glaciofluvial channels, they represent a group of penecontemporaneous glacigenic outwash fans. The topset beds grade landward into glaciofluvial outwash deposits. The bottomset and foreset beds coalesce seaward and are considered to comprise a single stratigraphic unit called the Advocate Harbour Member (Stea et al., 1986).

At Lower Five Islands deltaic deposits lie between the Harrington and North rivers. The northern part of the delta, believed to represent proximal deposition (Wightman, 1980), overlies the Carboniferous Parrsboro Formation. The southern part of the delta overlies the Triassic Scots Bay Formation, indicating the probability of buried fault contacts between these rock formations (Wightman, 1980). Major east-west trending faults (Figs. 2,3), that may be continuous with structures associated with the Grand Banks earthquake of 1929, occur within $3 \mathrm{~km}$ north of the shoreline (Figs. 2, 3).

The Quaternary delta at Economy Point runs from Carrs Brook to Hill Brook (Fig. 3) and forms most of the shore line, except for a small area where the Triassic bedrock protrudes into the basin to form Economy Point. This bedrock outcrop created a natural barrier for the main source of the meltwater discharge, which was probably focused along a valley now occupied by the Economy River (Fig. 3). Postglacial drainage from smaller brooks to the west of the Economy River may have altered the delta (Wightman, 1980).

\section{OBSERVATIONS AND INTERPRETATIONS}

\section{Lower Five Islands}

At Lower Five Islands, we examined five sections in detail over a distance of about $1400 \mathrm{~m}$. Here wave erosion has produced a cliff face up to about $9 \mathrm{~m}$ high in places, with extensive colluvial and vegetation cover. Two sections (sites B and E, Fig. 2) exposed all three delta facies (Fig. 4) and parts of each facies are exposed sporadically between the sections.

Bottomsets were exposed at three sections (sites B, C, and E, Fig. 2) up to a maximum thickness of $3 \mathrm{~m}$. The bottomsets are composed of laminated silt and clay with minor undulations and frequent normal faults. At one site (site C, Fig. 2), normal faults dip northward at 60 to $80^{\circ}$ representing a total offset of about $40 \mathrm{~cm}$ to the northwest. At site $\mathrm{E}$, faults dip gently (207@06 ${ }^{\circ}$ ) south-southwest and bottomset layers display large open folds. Convoluted laminations occur at the boundary of the bottomset foreset units. At site B (Fig. 2), layered clay and silty sand are folded, within a $60 \mathrm{~cm}$ wide deformed-zone vertically bounded by sub-horizontal beds of clayey-silt and silty-clay. The fold demonstrates layer shortening to the southwest, parallel to the slope of the delta at that location.

The overlying foreset deposits were examined at three sections with a maximum exposure of about $5 \mathrm{~m}$ (section $\mathrm{B}$, D, E; Fig. 2). The sediments consist of predominantly southwarddipping layered sediment. Generally, a coarsening-upward relationship is observed within the foreset units. Because of fluctuations in glacier melting during delta construction, the sediment is highly variable between sections.

Silty- to pebbly-sand is most common in the lowermost 


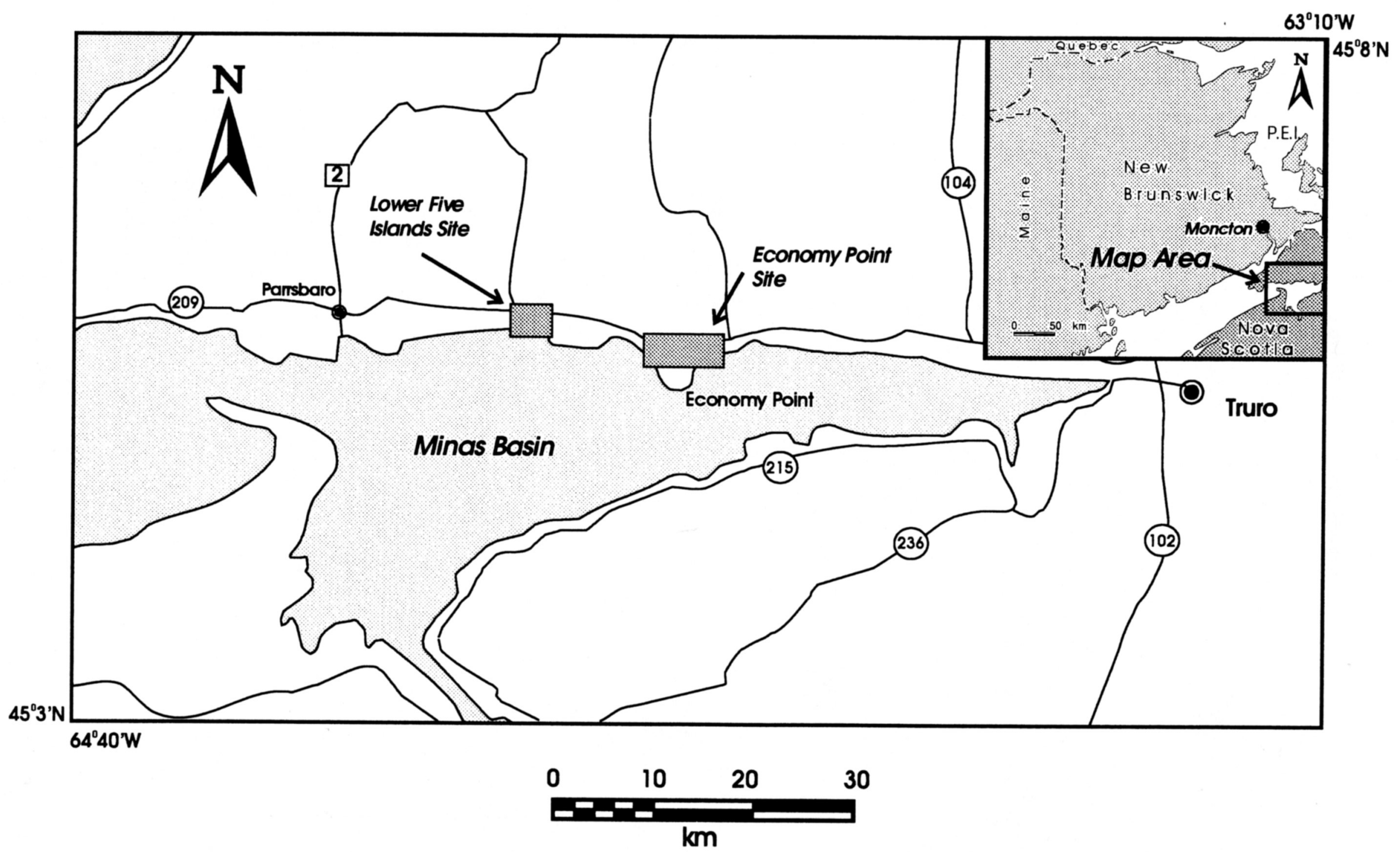

Fig. 1. Location of study sites at Five Islands - Economy Point area, Nova Scotia. Regional location of map area is indicated in insert map. 


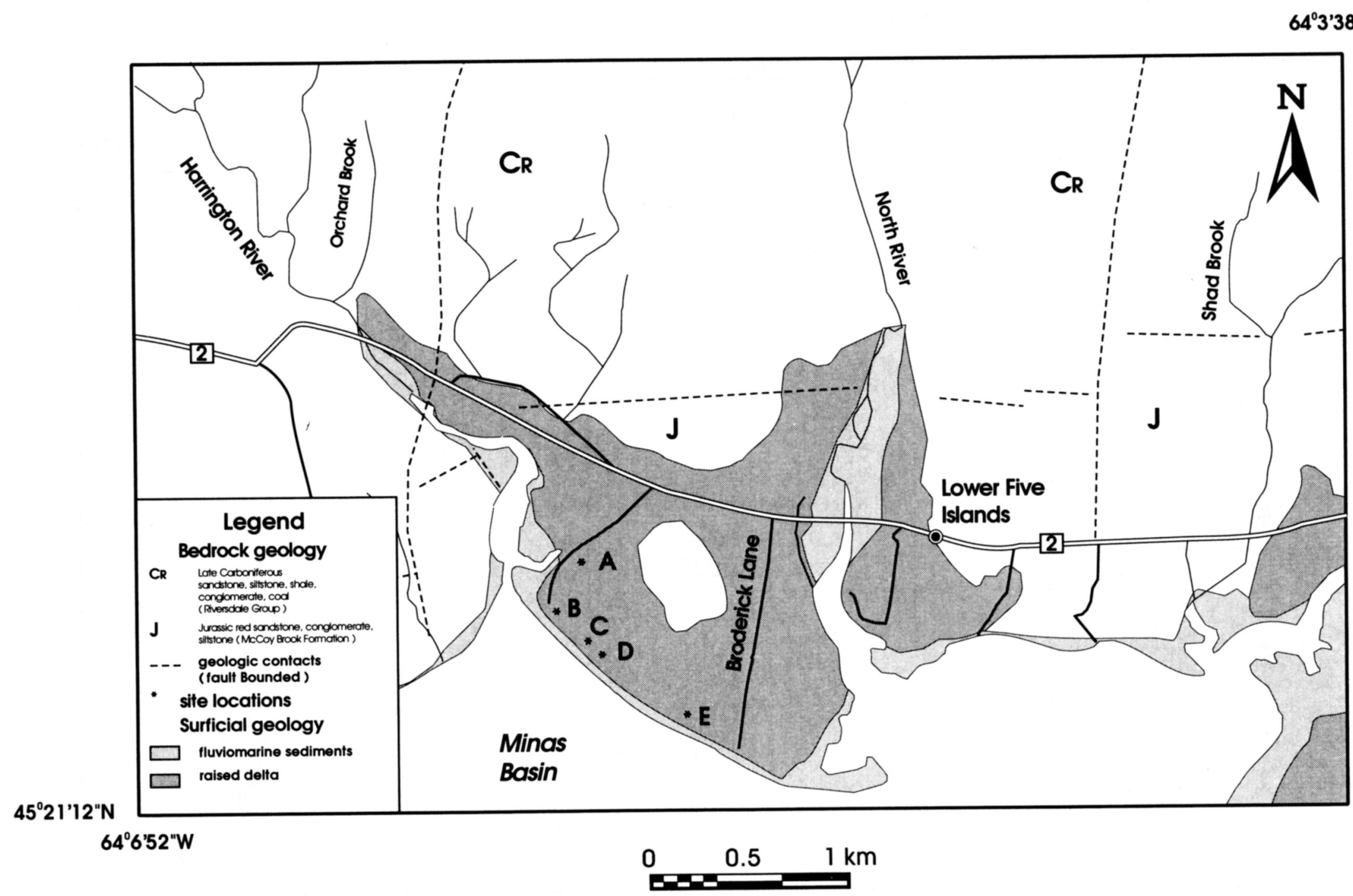

$45^{\circ} 25^{\prime} 33^{\prime \prime} \mathrm{N}$

Fig. 2. Location of sections $A$ to $E$ at Lower Five Islands. 


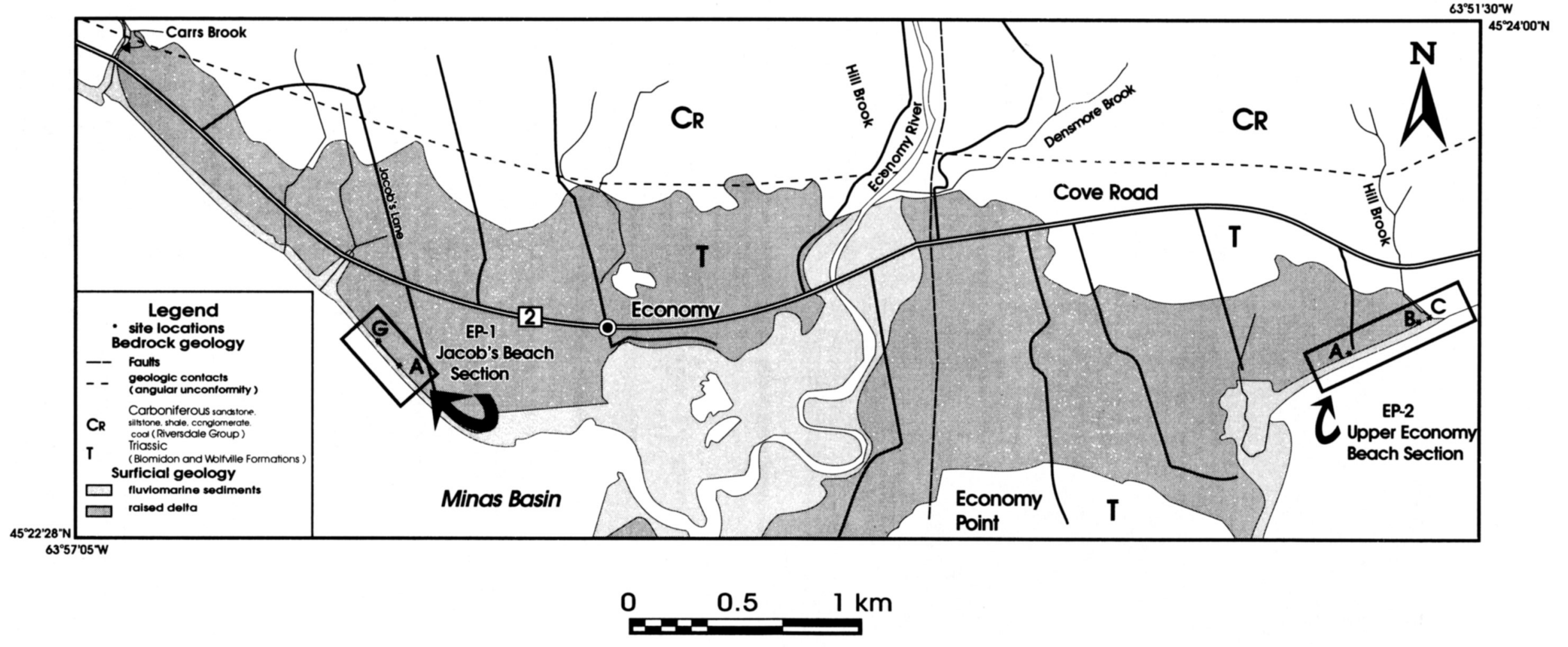

Fig. 3. Location of Economy Point: EP-1 sections A to G and EP-2 sections A, B and C. 


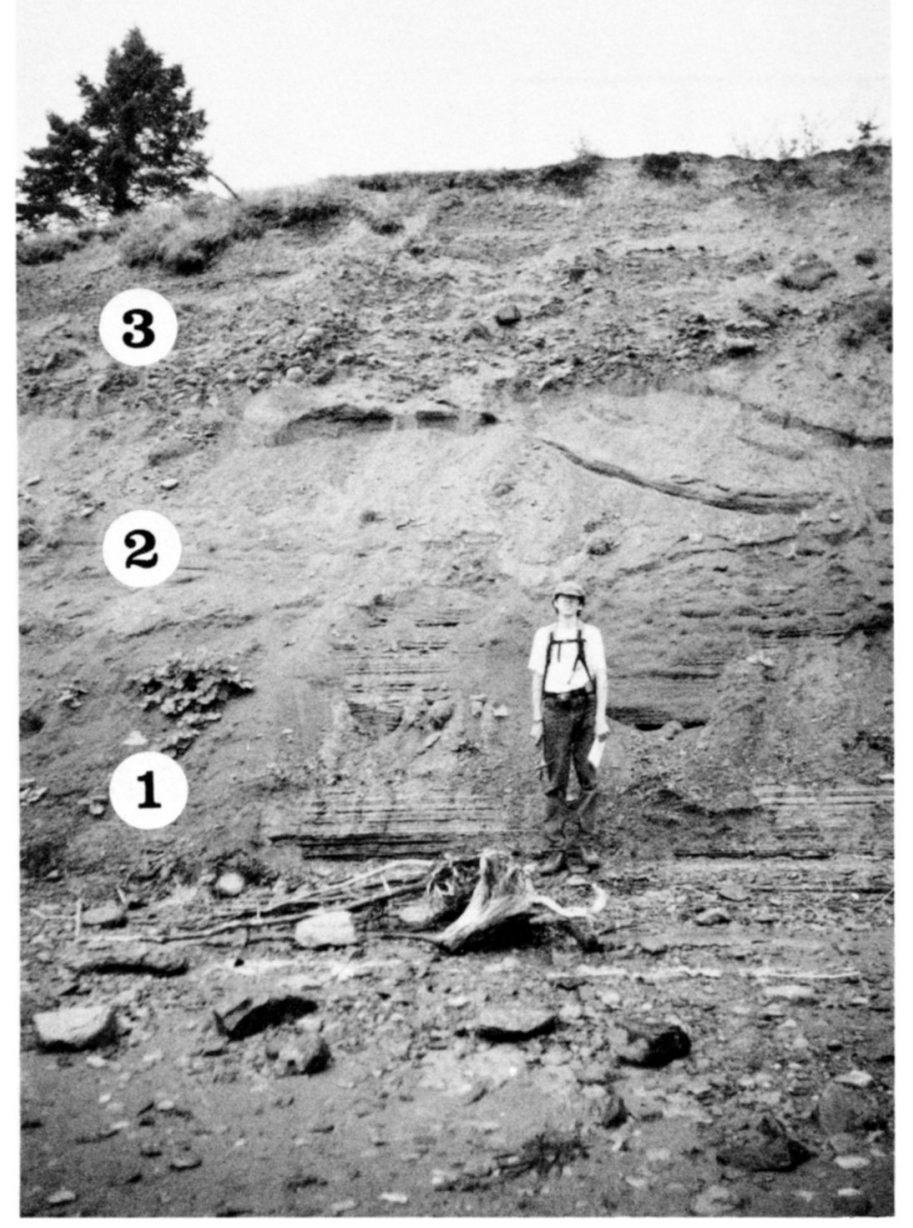

Fig. 4. Stratigraphic section at EP-2B exposing: (1) layered red clay and silty-sand bottomsets, and (2) layered and occasionally channeled sand foresets, both comprising the Advocate Harbour deposits, and overlying (3) gravel-rich topset beds.

foreset layers, changing upward into layers of coarse to pebbly sand, with an occasional lens of gravel and cobbles. The upper parts of the foresets have been channelled and although delta growth was predominantly southward, occasional eastwardand westward-dipping layers also occur. The foreset beds demonstrate northward and southward-dipping normal faults that are offset by as much as $20 \mathrm{~cm}$ (see MacDougall, 1996). Faulting is unit-confined and, with the exception of the fluidescape structures, rarely continues upwards through the topsets or downwards through the bottomsets. The style of deformation is consistent with failure during southward extension of the delta foreslope.

The foresets are unconformably overlain by layered, gravelly topsets, 1 to $3 \mathrm{~m}$ thick. The unit consists of predominantly horizontally-stratified layers of coarse pebbles $(2-5 \mathrm{~cm})$ and pebbly-sand with interstitial sand layers. The topset unit is cut, due to channel migration during deposition and sediment infill is variable. At some locations the topsets unconformably overlie bottomsets. Generally, topset deposits fine upward into layered pebbly sand to fine sand. Faulting is rarely seen at Lower Five Islands. Deformation commonly occurs as convoluted laminations, composed of large open folds, with wavelengths of $1.5 \mathrm{~m}$ and amplitudes of 90 to $100 \mathrm{~cm}$. The fold axes are vertical and strike northeastward indicating a northwestward-southeastward shortening direction. The deformation is probably the result of occasional collapse of the delta foreslope during late-stage growth into deeper water.

\section{Economy Point area}

At Economy Point, all three delta facies were exposed in $7 \mathrm{~m}$ high sections only along the eastern side of the delta at Upper Economy beach (EP-2A, B, and C; Fig. 3). Topset beds and overlaying postglacial deposits were also examined along a $2.5 \mathrm{~m}$ shorecliff at the western side of the delta at Jacob's Lane beach (EP-1; Fig. 3). Diamicton was found underlying bottomset deposits at EP-2C (Fig. 3). Here, reddish brown diamicton is exposed in the lower $2 \mathrm{~m}$. The diamicton is dense and compacted with abundant clasts, from pebble to boulder in size, in a variety of lithologies. The clasts are faceted and highly striated, with orientation of the longest axis towards the southeast (MacDougall, 1996). The diamicton is interpreted as till. At this section, the till is overlain by 1 $\mathrm{m}$ of flat-lying, laminated silt-clay representing muddy bottomsets.

Where exposed (EP-2B, C; Fig. 4) the bottomsets are comprised of layered red clay, silty and sand. They are commonly horizontally stratified, with regular layers, 2 to $3 \mathrm{~cm}$ in thickness. Occasional convolutions and highly deformed areas occur as zones interbedded with underlying and overlying, undeformed beds. Deformation is mainly seen as folds and as ball and pillow structures. The disturbance is layerconfined and was likely penecontemporaneous, due to loading and density differences between the layers.

The bottomsets are overlain by southeastward-dipping, layered sand foreset beds. The foreset unit has been cut by fluvial, topset and post-glacial channels. The foreset unit is overlain by a unit of cobbles, gravel and sand beds (topsets) which is overlain by postglacial waterlain deposits and colluvium. In many places the waterlain material appears conformable with underlying topsets, although an erosional contact can be recognized occasionally. The waterlain material varies from a sand to silty-sand with rare pebbles, charcoal fragments and pebble-rich lenses. The material likely represents a composite unit mainly derived from Holocene river flooding, but may in part have been resedimented from a tsunami (cf. Clague and Bobrowski, 1994) or storm-wave event.

\section{DEFORMATION OF TOPSET UNIT}

Vertical deformation structures are common in the topset beds at Economy Point. At EP-2A, the lower $3 \mathrm{~m}$ of the section exposes alternating sand and gravel-rich topset layers overlain by about $0.8 \mathrm{~m}$ of sub-horizontal, postglacial, layered sand (Fig. 5). A dewatering structure passes vertically through the exposed topsets and terminates at the basc of the overlying sand unit (Fig. 5). The dewatering structure forms a $40 \mathrm{~cm}$ wide zone of vertically inclined pebbles 


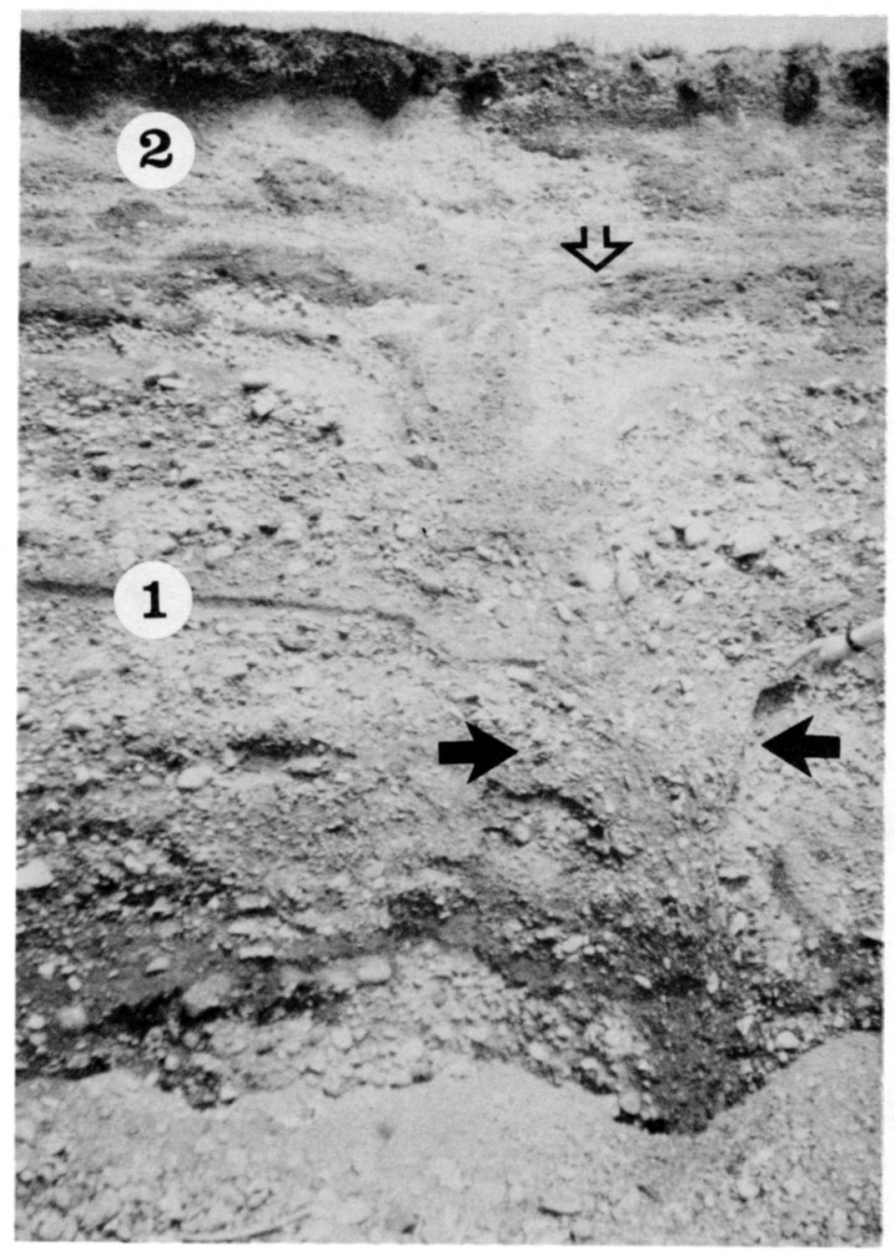

Fig. 5. Dewatering structure at EP-2A between black arrows, cutting sand and gravel topset layers (1) and terminating at (open arrow) the base of the overlaying postglacial sand unit (2); note down-folded topset layers (below left of open arrow) due to loss of strength and subsidence of underlying material. Section exposure is approximately $2 \mathrm{~m}$ high.

and convoluted (down-folded) layers within a vertical wedgeshaped zone, narrowing downward. At the top of the structure, sand layers are down-folded (dish-shaped), suggesting more than $20 \mathrm{~cm}$ of settling of the uppermost topset layers (Fig. 5). The deformation suggests fluidization and subsidence due to formation of the dewatering structure, prior to deposition of the postglacial sand unit.

Seven other vertical dewatering structures were found in the topset unit, exposed over a distance of about $100 \mathrm{~m}$, along shorecliff exposures at the western side of the delta (sites EP1-A to G; Figs. 6a, 6b, 7a, 7b). Deposits here consist of layered gravel of various size range, and sand with a distinct red colour associated with the weathered Triassic bedrock of the area. Gravel appears to be well stratified but is cut by scour and fill channels. The unit is interpreted as topset deposits. A layer of mixed sand and pebbles up to 40 $\mathrm{cm}$ thick in places, interpreted as postglacial waterlain (likely floodplain) deposits, unconformably overlies the topsets. A weathering profile and surface vegetation extend downward to about $30 \mathrm{~cm}$ from the surface. Fragments of preserved charcoal (wood) are dispersed sporadically throughout the area at the base of the postglacial sediments. A sample was recovered at site EP-2D (Fig. 6b) that has been dated by radiocarbon at $1870 \pm 70$ years.

Although no two dewatering structures are identical, they all demonstrate a degree of commonality (Figs. 5, 6a, $6 \mathrm{~b}, 7 \mathrm{a}, 7 \mathrm{~b})$. The structures commonly represent a more or less wedge-shaped vertical cylinder, narrowing downward, continuous to unknown depths below the exposure. The structures are recognizable by a noticeable deviation in cobble and pebble orientation that change from a sub-horizontal inclination to near-vertical inclinations, within a vertical zone of resedimented sand and gravel (Fig. 6a). The wedgeshaped area of steeply dipping pebbles forms a vertical zone, with offset and down-folded bedding adjacent to the features (Figs. 5, 6a, 7a). In the uppermost tens of centimetres of the structures, clasts are inclined less steeply, and deformation from subsidence appears to diminish outward from the central area and upward from the base of the structures. Overlaying layers sag downward (for up to $30 \mathrm{~cm}$, Fig. 5) into the central part of some dewatering structures and the structures stop at the boundary of the overlying Holocene sand unit.

A few dewatering structures are wedge-shaped in width and height but only a few $\mathrm{cm}$ in thickness when exposed in three-dimensions. Some are apparently fracture infillings associated with normal faulting (Fig. 7b). This suggests that parts of some fluid-escape structures were fracture controlled, although no consistent fracture orientations were found.

\section{Discussion}

Convolute laminations, seen as crumpling or complicated folding of layers of sediment (Kuenen, 1953; Reineck and Singh, 1975), are often found in fine grained, unconsolidated fluvial, lacustrine and marine sediments; in some cases caused or modified by glacial activity. Classical interpretations of genesis attribute convoluted laminated deposits to several possible causes, including: rapid sedimentation (Reineck and Singh, 1975); wave-induced liquefaction (Dalrymple, 1979); glacier loading (Broster, 1991a); loss of support (Broster and Clague, 1987); percussion from iceberg or dropstones, slope disturbance or landslide (Broster, 1991b); and growth of river ice (Broster et al., 1993). Because they imply fluidization by the application of sudden shock to waterlain sediments, they can also be indicative of seismic occurrence (cf. Van Loon et al., 1995).

During seismic shaking, groundwater can be expelled along cracks or zones of weakness through overlying unsaturated sediments. Buried layers of saturated silty-sand or sandy-silt can take on the characteristics of a dense liquid, reducing bearing capacity of the fluidized sediment and causing overlying material to sink into the substrate (Bolt, 1995). During shaking pore fluids are displaced upward, fluidizing sediment within a vertical zone of disturbance and resedimentation and may be expelled at ground level. At the ground surface the resulting sediment-fluid expulsion forms a depression and/or sand accumulation, commonly 

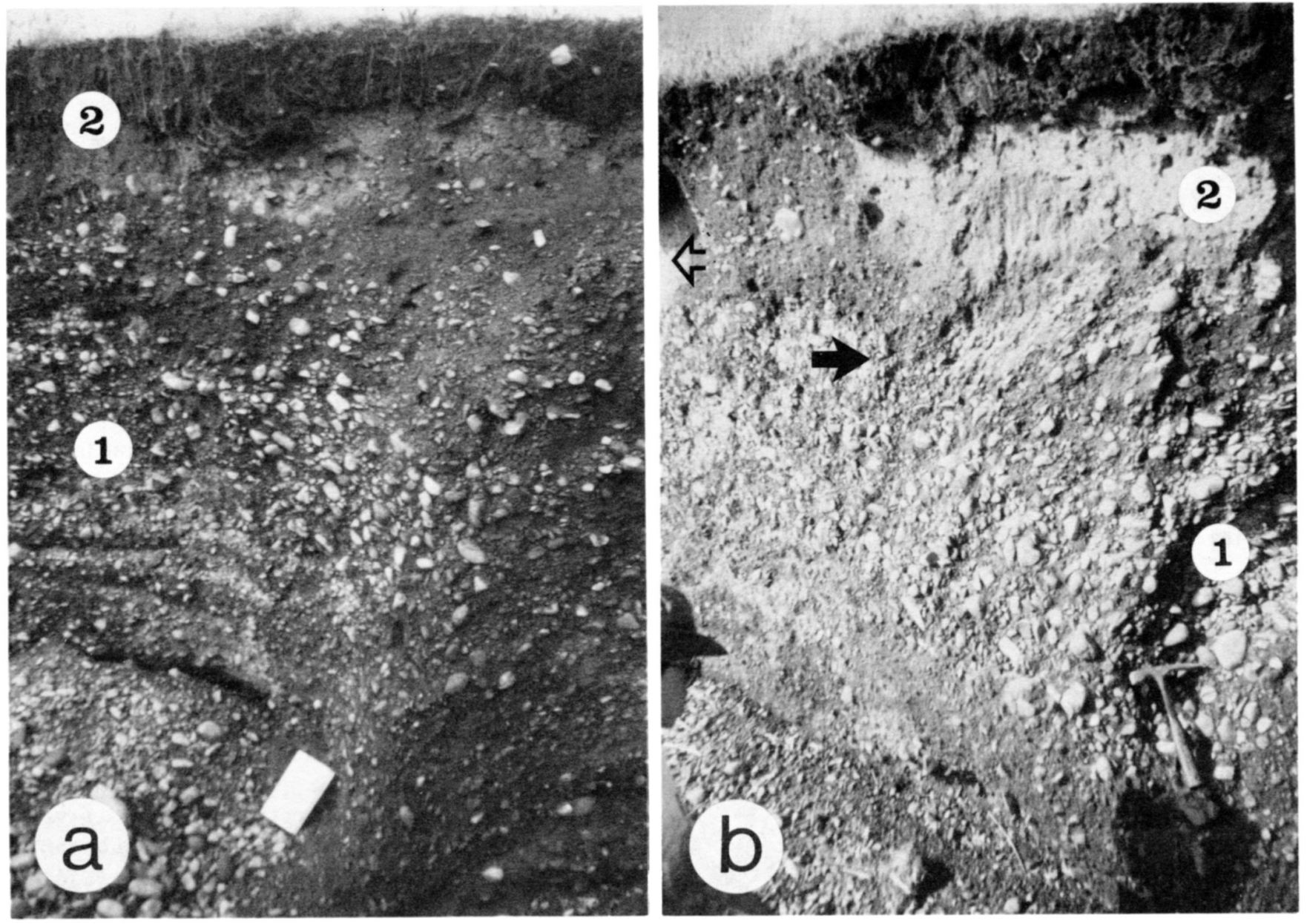

Fig. 6. Dewatering structure at EP-1C (6a), exposed as a cone-shaped zone of steeply-dipping clasts, cutting topset beds (1), widening upward and terminating at the base of the overlying unit (2). Notebook at base is about $20 \mathrm{~cm}$ long. Charcoal was recovered above the dewatering structure EP-2D in photo $6 \mathrm{~b}$, just left of the open arrow. The structure cuts topset sediments (1), and occurs to the right of the solid arrow, terminating at the base of the overlying unit (2). Scale is indicated by a rock hammer at bottom right.

called a "sand boil" or "sand volcano" (Bolt, 1995). In crosssection the sediment expulsions form dewatering structures or clastic dikes, that can often be traced downward along sub-vertical cracks or pipe-like zones of resedimented material to depths greater than $4 \mathrm{~m}$ (e.g., Tuttle et al., 1990; Broster et al., 1993).

A significant seismic disturbance, after deglaciation of the study area, would be expected to have affected the entire delta. With the exception of the fluid-escape structures, most of the deformation in the raised deltas studied here are apparently confined within layers or specific facies. Ball and pillow structures, convoluted laminations and numerous high angle faults occur throughout the bottomsets of the deltaic deposit. This deformation was most likely penecontemporaneous, due to loading during growth of the delta. Minor faulting and folding occurred in the foreset unit, associated with movement at the boundary with the underlying bottomsets. Slumping and faulting of foreset layers may be due to glacial movements or penecontemporaneous slope failure of the foreset beds towards deeper portions of the sedimentary basin. Topset beds demonstrated convoluted layers, with minor folds suggesting unit shortening in a southeastward direction, likely due to minor sliding.
The occurrence of dewatering structures at Economy Point has previously been recognized and attributed to several possible causes including: (1) formation as permafrost ice-wedges (Borns, 1965), and from expulsion of fluids; (2) during delta slumping (syndepositional); or (3) from seismic shock during the Holocene (Wightman, 1980; Stokes, 1988). Although the topset unit may have been exposed to subaerial climatic conditions in postglacial time, it is unlikely that the fluidescape structures represent permafrost features. There are no apparent cryoturbation features adjacent to the structures (e.g., Murton and French, 1994) or surface polygon patterns in overlying sediments (e.g., Black, 1976), although these could have been covered by the deposition of Holocene sediments. As Wightman (1980) noted, layering adjacent to the wedgeshaped structures are often down-folded, whereas ice wedge casts typically have adjacent upturned strata (Black, 1976). If permafrost conditions had existed, the ice wedge casts and surface polygon features would be expected to have been more widespread (e.g., Morgan, 1972; Black, 1976), or at least occurring in the upper deposits of both deltas. Local fault movements would have been equally as pervasive and would likely have produced structures permeating all facies. 

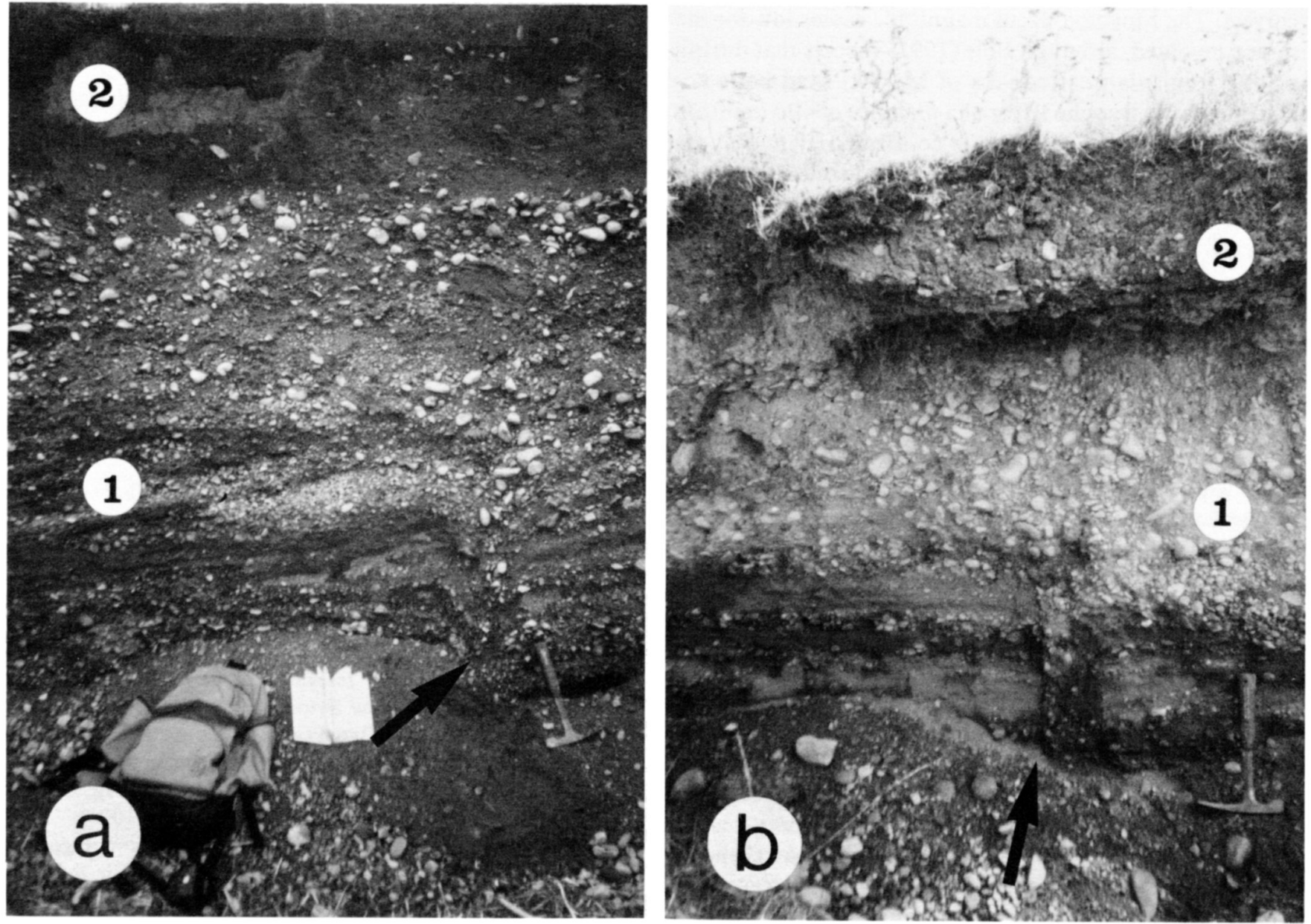

Fig. 7. Normal faulting and down-turned adjacent layering, at EP-1B (photo a) and EP1G (photo b) associated with a fluidization structure (7a, above arrow), and infilled fracture (7b, above arrow). Topsets and overlying floodplain sediments are indicated as 1 and 2, respectively; scale is indicated by a rock hammer in the lower right of both photos.

That the dewatering structures were found only at Economy Point, indicates that the deformation was due to specific characteristics of that deposit (e.g., lower strength, less stability or greater susceptiblity to fluidization than surrounding deposits). The style of deformation suggests that the sediments were unfrozen at the time of disturbance (e.g., Broster, 1991a; Broster et al., 1993) but not necessarily water-saturated. The dewatering structures extend to the top of the delta, which at present is approximately $2 \mathrm{~m}$ above mean sea level. This also may have been the elevation at the time of the deformation event, thus the top $2 \mathrm{~m}$ may have been unsaturated during the disturbance. However, the units are saturated at greater depths (below sea level) and fine grained sediments susceptible to liquefaction likely occur within 4 $m$ of ground surface.

The fluid-escape structures bear some resemblance to clastic dikes produced by glacial overriding (e.g., Broster, 1991a), but there is no supporting evidence for a glacier readvance after development of local glaciofluvial systems that merge with the topset deposits (Swift and Borns, 1967; Stea et al., 1986). Convoluted layers are associated with these dewatering structures as: (1) layers that were downfolded because of subsidence within or adjacent to a verti- cal fluidization (dewatering) structure, and (2) because of sagging from underlying subsidence during resedimentation of an underlying bed.

The areal extent of the dewatering structures is not known, but it is possible that more exist throughout the topset unit. Nonetheless, the frequency of fluid-escape structures found in the topset unit at Economy Point, indicates that the delta experienced a catastrophic disturbance in postglacial time. Charcoal (Sample Beta-80755) was recovered from the lower $10 \mathrm{~cm}$ of the Holocene sand unit overlying a dewatering structure at EP-1D (Fig. 6b). The sample (dated by Beta Analytic Inc. of Miami, Florida) yielded a corrected radiocarbon age of $1870 \pm 70$ years, which may be synonymous with the dewatering event or much younger. As the sample may have also been contaminated by young carbon, this date represents a minimum age that should be confirmed by additional dating. Examination of historical records for seismic events in the area (Leblanc and Burke, 1985) indicates that an earthquake (estimated M 5+) occurred in 1855, centred around Moncton, New Brunswick, approximately $100 \mathrm{~km}$ to the west (Fig. 1, insert). The date of the event is wellestablished and presently represents the best candidate as a cause of the fluid-escape structures, if the radiocarbon age 
is correct. The Moncton event magnitude seems low for the distance involved, although Bolt (1995) reports that during the 1977 Romanian earthquake of $M_{S} 7.2$, sand boils occurred along the Danube River at a distance of $400 \mathrm{~km}$ from the epicentre. If the 1855 date is confirmed by additional radiocarbon dating, the estimated magnitude of the Moncton event may need to be re-assessed.

\section{Conclusions}

Two raised glaciomarine deltas were examined for deformation that could be attributed to possible neotectonic seismic shaking. Several examples of interlayer or interunit deformation were found that were interpreted as penecontemporaneous deformation and common to particular mechanisms of formation and facies. Eight vertical dewatering structures were found in the topset facies at Economy Point, Nova Scotia, seven of these within a distance of 100 $\mathrm{m}$. The structures are interpreted to represent catastrophic expulsion of pore water due to seismic shock. Radiocarbon dating suggests that the disturbance may have been associated with the 1855 (M 5+) earthquake of Moncton, New Brunswick.

Further study is required to confirm the timing of the disturbance, to identify any other areas of deformation and to determine the exact origin of the Holocene waterlain sediments at Economy Point. Nonetheless, these preliminary results demonstrate that the physical structure of deltaic sediments can provide a record of neotectonic activity and contribute valuable data for assessment of earthquake occurrence and/ or recurrence. For neotectonic studies elsewhere, deformation associated with catastrophic fluidization of a delta topset facies or overlying Holocene sediments, is considered to be the best indication of possible seismic shock-induced deformation.

\section{ACKNOWLedgements}

Financial support was received from Atomic Energy Control Board under Research Contact \#3.157.1 and an NSERC Operating Grant to Broster. The data presented here forms part of a UNB Masters project by MacDougall. Damean Robbins assisted in field studies, and radiocarbon analysis was performed by Beta Analytic Inc. of Miami, Florida. We would like to thank also, Larry Mayer and Ian Spooner for review of an earlier manuscript, and especially Joe Wallach for suggesting that we examine these deposits and for enthusiastic discussions on this and other relevant topics.

BLACK, R.F. 1976. Periglacial features indicative of permafrost: ice and soil wedges. Quaternary Research, 6, pp. 3-26.

Bolt, B.A. 1995. Earthquakes (revised). W.H. Freeman and Company, $331 \mathrm{p}$.

BorNs, H.W., JR. 1965. Late-glacial ice wedge casts in northern Nova Scotia, Canada. Science, 148, pp. 1223-1226.

Broster, B.E. 1991 a. Glacitectonic deformation in sediment and bedrock: Hat Creek, British Columbia. Géographie physique et Quaternaire, 45, pp. 5-20.
-..- 1991b. Application of glacial geology in the assessment of neotectonics in coastal environments. CANQUA Conference Abstracts, Atlantic Geology, 27, p. 233.

Broster, B.E. and ClAGUE, J.J. 1987. Advance and retreat glacigenic deformation at Williams Lake, British Columbia. Canadian Journal of Earth Sciences, 24, pp. 1421-1430.

Broster, B.E., Allen, P., and BURKe, K.B.S. 1993. A multidisciplinary assessment of postglacial seismic disturbance: Miramichi area, New Brüswick, Canada. Quaternary International, 20, pp. 153-161.

CLAGUE, J.J. and BoBrowsKi, P.T. 1994. Evidence for a large earthquake and tsunami 100 - 400 years ago on western Vancouver Island, British Columbia. Quaternary Research, 41, pp. 176184.

DAlRYMPLE, R.W. 1979. Wave-induced liquefaction: a modem example from the Bay of Fundy. Sedimentology, 26, pp. 835-844.

KUENEN, Ph.H. 1953. Significant features of graded bedding. American Association of Petroleum Geologists Bulletin, 37, pp. 10441066.

Leblanc, G. and BurKe, K.B.S. 1985. A re-evaluation of the 1817 , 1855, 1869, and 1904 Maine-New Brunswick area earthquakes. Earthquake Notes, 56, pp. 107-123.

MacDougall, D.A. 1996. Soft-sediment deformation structures in postglacial deltas: examples from three locations in eastern Canada and their relevance to neotectonics. M.Sc. thesis, University of New Brunswick, 136 p.

MacDougall, D.A. and Broster, B.E. 1995. Convoluted laminations in waterlain sediments: three examples from eastern Canada and their relevance to neotectonics. Atomic Energy Control Board, Information Report - 0606, 102 p.

Morgan, A.V. 1972. Late Wisconsinan ice-wedge polygons near Kitchener, Ontario, Canada. Canadian Journal of Earth Sciences, 9, pp. 607-617.

Murton, J.B. and French, H.M. 1994. Cryostructures in permafrost, Tuktoyaktuk coastlands, western Arctic, Canada. Canadian Journal of Earth Sciences, 31, pp. 737-747.

ReineCK, H.-E. and SingH, I.B. 1975. Depositional Sedimentary Environments. Springer-Verlag, New York, 439 p.

Stea, R.R., Fink, P.W., and Wightman, D.M. 1986. Quaternary geology and till geochemistry of the western part of Cumberland County, Nova Scotia. Geological Survey of Canada, Paper 85-17, $58 \mathrm{p}$.

Stokes, T.R. 1988. A documentation of structures in unconsolidated sediments along the north shore of the Minas Basin, Nova Scotia: a reconnaissance neotectonic survey. Atomic Energy Control Board, Contribution 98-01, 96 p.

SwifT D.J.P. and BorNs, H.W., JR. 1967. A raised fluviomarine outwash terrace, north shore of the Minas Basin, Nova Scotia. Journal of Geology, 75, pp. 693-710.

Tuttle, M., Law, K.T., Seeber, L., and Jacob, K. 1990. Liquefaction and ground failure induced by the 1988 Saquenay, Quebec, earthquake. Canadian Geotechnical Journal, 27, pp. 580-589.

Van Loon, A.J., Brodzikowski, K., and Zielinski, T. 1995. Shockinduced resuspension deposits from a Pleistocene proglacial lake (Kleszczów Graben, central Poland). Journal of Sedimentary Research, A65, pp. 417-422.

Wightman, D.M. 1980. Late Pleistocene glaciofluvial and glaciomarine sediments on the north side of the Minas Basin, Nova Scotia. Ph.D. thesis, Dalhousie University, Halifax, Nova Scotia, 426 p. 